Marine Ecology Progress Series

Celebrating $\mathbf{4 0}$ years of global impact

Peck, Myron A.; Richardson, Katharine; Snelgrove, Paul V.R.; Wilson, Rory P.

Published in:

Marine Ecology Progress Series

DOI:

10.3354/meps 12892

Publication date:

2019

Document version

Publisher's PDF, also known as Version of record

Document license:

CC BY

Citation for published version (APA):

Peck, M. A., Richardson, K., Snelgrove, P. V. R., \& Wilson, R. P. (2019). Marine Ecology Progress Series:

Celebrating 40 years of global impact. Marine Ecology Progress Series, 612, 1-5.

https://doi.org/10.3354/meps 12892 


\title{
EDITORIAL
}

\section{Marine Ecology Progress Series: celebrating 40 years of global impact}

\author{
Myron A. Peck ${ }^{1, *}$, Katharine Richardson ${ }^{2}$, Paul V. R. Snelgrove ${ }^{3}$, Rory P. Wilson ${ }^{4}$ \\ ${ }^{1}$ Institute for Marine Ecosystem and Fisheries Science, Center for Earth System Research and Sustainability, \\ University of Hamburg, 22767 Hamburg, Germany \\ ${ }^{2}$ Center for Macroecology, Evolution and Climate, Department of Biology, University of Copenhagen, 2100 Copenhagen, Denmark \\ ${ }^{3}$ Canada Research Chair in Boreal \& Cold Ocean Systems, Ocean Sciences Centre, Memorial University of Newfoundland, \\ St. John's, NL A1C 5S7, Canada \\ ${ }^{4}$ Biosciences, College of Science, Swansea University, Swansea SA2 8PP, Wales, UK
}

\section{INTRODUCTION}

The first issue of Marine Ecology Progress Series (MEPS) was published on July 30th, 1979. By the end of that year the first volume (Issues 1 to 4 ) included an impressive 46 papers authored by scientists representing nations from Europe, North America, Asia and Africa. Although German and US scientists led the majority (61\%) of articles in Vol. 1, MEPS quickly grew into a global journal (Fig. 1). This diversity of authorship is matched by the wide breadth of topics embraced in each and every volume (from bacteria and foraminifera to jellyfish and sharks, from singlespecies studies in the laboratory and the wild to extensive community-level field research, sometimes over decades). To help celebrate MEPS' auspicious 40th birthday in 2019 and look back on the broad impact of MEPS on the field of marine ecology, we briefly present and describe the unique contributions by MEPS' 40 most highly-cited studies - the 'MEPS Top 40 at $40^{\prime}$ (Table 1).

\section{EXPERIMENTAL DESIGN AND ANALYSIS}

Some of the most highly-cited studies within MEPS introduced statistical techniques that are now commonplace when designing field studies and/or analyzing ecological data. These techniques include sampling designs appropriate for testing differences among field locations (Clarke \& Green 1988) and the

\footnotetext{
*Corresponding author: myron.peck@uni-hamburg.de
}

use of multi-dimensional scaling in revealing patterns in distribution among field stations to help identify environmental drivers or indicator species (Field et al. 1982, Clarke \& Ainsworth 1993). Other well-cited studies introduced biodiversity indices (e.g. Delta, Delta* or variation in taxonomical distinctness) (Warwick \& Clarke 1995, Clarke \& Warwick 2001), which have become mainstays in research examining ecosystem change along environmental gradients.

\section{NEW MEASUREMENT TECHNIQUES}

Papers unveiling powerful measurement techniques that greatly advanced marine ecology are also among some of the most highly-cited papers in MEPS. In order to advance studies of nutrient cycling, Hoppe (1983) introduced a technique to measure in situ enzymatic degradation of macromolecules, a key step controlling the rate of production of dissolved organic carbon. Several studies reported improvements in the chemical measurement of algal pigments (Wright et al. 1991, Mackey et al. 1996, Zapata et al. 2000), paving the way for more precise estimates of standing stocks of different phytoplankton groups. In order to enhance understanding of food web structure, Hobson \& Welch (1992) used measurements of stable-carbon and -nitrogen isotope ratios in the Arctic to create a novel isotopic food web model. A few years later, by summarizing and com-

(C) The authors 2019. Open Access under Creative Commons by Attribution Licence. Use, distribution and reproduction are unrestricted. Authors and original publication must be credited. 


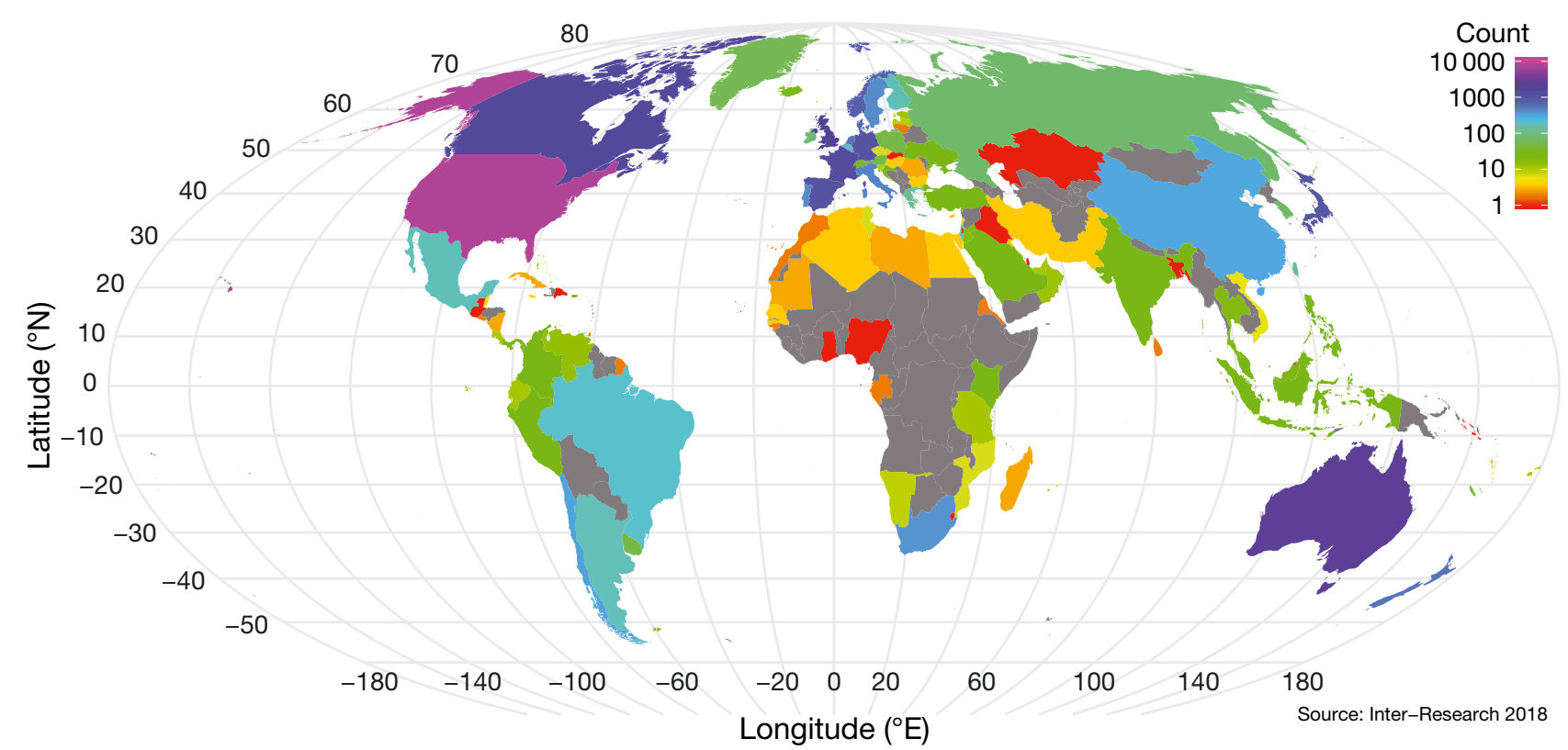

Fig. 1. A global view of MEPS' authorship based on the country affiliation of authors of published manuscripts. The cumulative number is shown for papers published between 1997 and 2018 (Vol. 156 to 604)

paring 876 values of Carbon-13, France (1995) documented differences between marine and freshwater taxa and between phytoplankton and benthic algae in marine habitats. In reviewing chemical measurements on fish otoliths, calcium carbonate ear bone structures containing growth rings, Campana (1999) demonstrated the wealth of information that these structures could provide on the life history of individuals, including stage-specific habitat utilization. This approach played a central role in launching a wide range of studies on population connectivity, a major research challenge in basic marine ecology and in fisheries management.

\section{FUNDAMENTAL ECOLOGY OF ORGANISMS AND COMMUNITIES}

The field of marine ecology requires fundamental understanding of the trophodynamic structure and function of marine ecosystems, nowadays a prevalent research theme in studies published in MEPS. In MEPS' most highly-cited article, Azam et al. (1983) described the roles of water-column bacteria and microplankton such as heterotrophic flagellates in the 'microbial loop'. Subsequent work described specific aspects of the 'microbial loop' such as bacterial protein synthesis (Simon \& Azam 1989) and generated relationships for predicting bacterial production in the water column and sediments in different marine and freshwater systems (Cole et al. 1988). Funda- mental MEPS studies also advanced knowledge on the growth physiology and life-cycle dynamics of key groups of planktonic and benthic organisms that helped set future research directions. This includes research on (1) phytoplankton nutrient requirements (Dortch 1990, Egge \& Aksnes 1992), (2) the metabolic and lipid dynamics of zooplankton (Kiørboe et al. 1985, Lee et al. 2006), and (3) larval dynamics and the process of settlement and recruitment in benthic invertebrates (Gosselin \& Qian 1997, Hunt \& Scheibling 1997, Pechenik 1999). Three well-cited papers revealed fundamental aspects of coral ecology including how (1) reef-building corals reproduce using fragmentation (Highsmith 1982), (2) healthy corals have a rich, species-specific bacterial community (Rohwer et al. 2002) and (3) the mucus of corals contains antibiotic protection against invasive microbes (Ritchie 2006). Fish ecological research documented species-specific patterns of trophic niche breadth and size-based feeding strategies (Scharf et al. 2000). Other papers provided novel comments and syntheses on key processes such as epibiosis (Wahl 1989), top-down control (Verity \& Smetacek 1996), and the nursery function of ecosystem engineers such as seagrasses (Heck et al. 2003).

\section{MARINE ECOLOGY IN THE ANTHROPOCENE}

Across 4 decades marked by increasing anthropogenic pressures, MEPS documented impacts of 
Table 1. The 40 most-cited articles published in MEPS. Numbers of citations are based on a search performed on 25 th October 2018 using CrossRef data. This dataset underestimates full citation numbers, typically by a factor of about 2 (only citation counts of participating publishing outlets are included), but was selected over other data sources such as Google Scholar because of its reliability for comparison purposes

\begin{tabular}{|c|c|c|c|}
\hline Citations & Authors & Year & Title \\
\hline 2108 & Azam et al. & 1983 & The ecological role of water-column microbes in the sea \\
\hline 1390 & Cloern & 2001 & Our evolving conceptual model of the coastal eutrophication problem \\
\hline 1076 & Clarke \& Ainsworth & 1993 & A method of linking multivariate community structure to environmental variables \\
\hline 964 & Campana & 1999 & Chemistry and composition of fish otoliths: pathways, mechanisms and applications \\
\hline 920 & Clarke \& Green & 1988 & Statistical design and analysis for a 'biological effects' study \\
\hline 833 & Field et al. & 1982 & A practical strategy for analysing multispecies distribution patterns \\
\hline 760 & Simon \& Azam & 1989 & Protein content and protein synthesis rates of planktonic bacteria \\
\hline 641 & Kemp et al. & 2005 & Eutrophication of Chesapeake Bay: historical trends and ecological interactions \\
\hline 613 & Hobson \& Welch & 1992 & $\begin{array}{l}\text { Determination of trophic relationships within a high Arctic marine food web using } \\
\delta^{13} \mathrm{C} \text { and } \delta^{15} \mathrm{~N} \text { analysis }\end{array}$ \\
\hline 599 & Wright et al. & 1991 & $\begin{array}{l}\text { Improved HPLC method for the analysis of chlorophylls and carotenoids from } \\
\text { marine phytoplankton }\end{array}$ \\
\hline 598 & Rogers & 1990 & Reponses of coral reefs and reef organisms to sedimentation \\
\hline 596 & Mackey et al. & 1996 & $\begin{array}{l}\text { CHEMTAX - a program for estimating class abundances from chemical markers: } \\
\text { application to HPLC measurements of phytoplankton }\end{array}$ \\
\hline 582 & Cole et al. & 1988 & Bacterial production in fresh and saltwater ecosystems: a cross-system overview \\
\hline 581 & Lester et al. & 2009 & Biological effects within no-take marine reserves: a global synthesis \\
\hline 553 & Wahl & 1989 & Marine epibiosis. I. Fouling and antifouling: some basic aspects \\
\hline 497 & Rohwer et al. & 2002 & Diversity and distribution of coral-associated bacteria \\
\hline 480 & Gray et al. & 2002 & Effects of hypoxia and organic enrichment on the coastal marine environment \\
\hline 457 & France & 1995 & Carbon-13 enrichment in benthic compared to planktonic algae: foodweb implications \\
\hline 441 & Zapata et al. & 2000 & $\begin{array}{l}\text { Separation of chlorophylls and carotenoids from marine phytoplankton: a new HPLC } \\
\text { method using a reversed phase } C_{8} \text { column and pyridine-containing mobile phases }\end{array}$ \\
\hline 413 & Clarke \& Warwick & 2001 & A further biodiversity index applicable to species lists: variation in taxonomic distinctness \\
\hline 412 & Pörtner & 2008 & Ecosystem effects of ocean acidification in times of ocean warming: a physiologist's view \\
\hline 404 & Ritchie & 2006 & $\begin{array}{l}\text { Regulation of microbial populations by coral surface mucus and mucus-associated } \\
\text { bacteria }\end{array}$ \\
\hline 395 & Hoppe & 1983 & $\begin{array}{l}\text { Significance of exoenzymatic activities in the ecology of brackish water: measure- } \\
\text { ments by means of methylumbelliferyl-substrates }\end{array}$ \\
\hline 392 & Warwick \& Clarke & 1995 & $\begin{array}{l}\text { New 'biodiversity' measures reveal a decrease in taxonomic distinctness with } \\
\text { increasing stress }\end{array}$ \\
\hline 390 & Purcell et al. & 2007 & $\begin{array}{l}\text { Anthropogenic causes of jellyfish blooms and their direct consequences for humans: } \\
\text { a review }\end{array}$ \\
\hline 379 & Heck et al. & 2003 & Critical evaluation of the nursery role hypothesis for seagrass meadows \\
\hline 377 & Scharf et al. & 2000 & $\begin{array}{l}\text { Predator size-prey size relationships of marine fish predators: interspecific variation } \\
\text { and effects of ontogeny and body size on trophic-niche breadth }\end{array}$ \\
\hline 355 & Lee et al. & 2006 & Lipid storage in marine zooplankton \\
\hline 346 & Egge \& Aksnes & 1992 & Silicate as regulating nutrient in phytoplankton competition \\
\hline 345 & Gosselin \& Qian & 1997 & Juvenile mortality in benthic marine invertebrates \\
\hline 338 & Dortch & 1990 & The interaction between ammonium and nitrate uptake in phytoplankton \\
\hline 322 & Kurihara & 2008 & $\begin{array}{l}\text { Effects of } \mathrm{CO}_{2} \text {-driven ocean acidification on the early developmental stages of } \\
\text { invertebrates }\end{array}$ \\
\hline 319 & Michaelidis et al. & 2005 & $\begin{array}{l}\text { Effects of long-term moderate hypercapnia on acid-base balance and growth rate in } \\
\text { marine mussels Mytilus galloprovincialis }\end{array}$ \\
\hline 318 & Pechenik & 1999 & $\begin{array}{l}\text { On the advantages and disadvantages of larval stages in benthic marine invertebrate } \\
\text { life cycles }\end{array}$ \\
\hline 316 & Hunt \& Scheiblin & 1997 & Role of early post-settlement mortality in recruitment of benthic marine invertebrates \\
\hline 311 & Friedlander \& DeMartini & 2002 & $\begin{array}{l}\text { Contrasts in density, size, and biomass of reef fishes between the northwestern and } \\
\text { the main Hawaiian islands: the effects of fishing down apex predators }\end{array}$ \\
\hline 306 & Kiørboe et al. & 1985 & $\begin{array}{l}\text { Bioenergetics of the planktonic copepod Acartia tonsa: relation between feeding, egg } \\
\text { production and respiration, and composition of specific dynamic action }\end{array}$ \\
\hline 305 & Highsmith & 1982 & Reproduction by fragmentation in corals \\
\hline 304 & Verity \& Smetacek & 1996 & Organism life cycles, predation, and the structure of marine pelagic ecosystems \\
\hline 292 & Kaiser et al. & 2006 & Global analysis of response and recovery of benthic biota to fishing \\
\hline
\end{tabular}


human activities on marine species, communities, and ecosystems. The first volume of MEPS contained several studies documenting impacts of environmental stressors (e.g. hypoxia, oil, metals) on the vital rates of marine fauna. Not surprisingly, therefore, our Top 40 contain seminal research efforts documenting aspects of the human footprint on marine habitats. For example, studies highlighted the deleterious impacts of (1) eutrophication on coastal habitats (Cloern 2001, Gray et al. 2002, Kemp et al. 2005), (2) sedimentation and the destruction of coral habitats (Rogers 1990), and (3) fishing on benthic and pelagic invertebrate and fish communities (Friedlander \& DeMartini 2002, Kaiser et al. 2006, Lester et al. 2009). Three studies discussed impacts of ongoing ocean acidification on invertebrates and/or fish (Michaelidis et al. 2005, Kurihara 2008, Pörtner 2008), while another study reflected on how interaction of various anthropogenic stressors may have increased jellyfish populations world-wide with substantial economic costs to human communities (Purcell et al. 2007).

\section{HORIZONS IN MARINE ECOLOGY}

Against this backdrop of highly-cited research on such a wide range of subjects, we are pleased to announce that, to celebrate its $40^{\text {th }}$ anniversary, MEPS plans to publish a number of perspective articles written by recognized leaders in different fields of marine ecology. Each Ecological Memoir will cover a specific topic (from marine microbes to marine management), chronicling how the field has advanced and providing an outlook on the most exciting developments and future avenues of research in that area. We hope that our readers will find these articles interesting and inspiring, especially the students and early career researchers who will produce the next 40 years of outstanding marine ecological research.

\section{LITERATURE CITED}

Azam F, Fenchel T, Field JG, Gray JS, Meyer-Reil LA, Thingstad F (1983) The ecological role of water-column microbes in the sea. Mar Ecol Prog Ser 10:257-263

* Campana SE (1999) Chemistry and composition of fish otoliths: pathways, mechanisms and applications. Mar Ecol Prog Ser 188:263-297

Clarke KR, Ainsworth M (1993) A method of linking multivariate community structure to environmental variables. Mar Ecol Prog Ser 92:205-219

Clarke KR, Green RH (1988) Statistical design and analysis for a 'biological effects' study. Mar Ecol Prog Ser 46: 213-226

Clarke KR, Warwick RM (2001) A further biodiversity index applicable to species lists: variation in taxonomic distinctness. Mar Ecol Prog Ser 216:265-278

Cloern JE (2001) Our evolving conceptual model of the coastal eutrophication problem. Mar Ecol Prog Ser 210: 223-253

Cole JJ, Findlay S, Pace ML (1988) Bacterial production in fresh and saltwater ecosystems: a cross-system overview. Mar Ecol Prog Ser 43:1-10

*Dortch Q (1990) The interaction between ammonium and nitrate uptake in phytoplankton. Mar Ecol Prog Ser 61: 183-201

* Egge JK, Aksnes DL (1992) Silicate as regulating nutrient in phytoplankton competition. Mar Ecol Prog Ser 83: 281-289

* Field JG, Clarke KR, Warwick RM (1982) A practical strategy for analysing multispecies distribution patterns. Mar Ecol Prog Ser 8:37-52

France RL (1995) Carbon-13 enrichment in benthic compared to planktonic algae: foodweb implications. Mar Ecol Prog Ser 124:307-312

Friedlander AM, DeMartini EE (2002) Contrasts in density, size, and biomass of reef fishes between the northwestern and the main Hawaiian islands: the effects of fishing down apex predators. Mar Ecol Prog Ser 230: 253-264

Gosselin LA, Qian PY (1997) Juvenile mortality in benthic marine invertebrates. Mar Ecol Prog Ser 146:265-282

Gray JS, Wu R, Or YY (2002) Effects of hypoxia and organic enrichment on the coastal marine environment. Mar Ecol Prog Ser 238:249-279

Heck K Jr, Hays C, Orth RJ (2003) Critical evaluation of the nursery role hypothesis for seagrass meadows. Mar Ecol Prog Ser 253:123-136

*Highsmith RC (1982) Reproduction by fragmentation in corals. Mar Ecol Prog Ser 7:207-226

*Hobson KA, Welch HE (1992) Determination of trophic relationships within a high Arctic marine food web using $\delta^{13} \mathrm{C}$ and $\delta^{15} \mathrm{~N}$ analysis. Mar Ecol Prog Ser 84:9-18

*Hoppe HG (1983) Significance of exoenzymatic activities in the ecology of brackish water: measurements by means of methylumbelliferyl-substrates. Mar Ecol Prog Ser 11: 299-308

*Hunt HL, Scheibling RE (1997) Role of early post-settlement mortality in recruitment of benthic marine invertebrates. Mar Ecol Prog Ser 155:269-301

Kaiser MJ, Clarke KR, Hinz H, Austen MCV, Somerfield PJ, Karakassis I (2006) Global analysis of response and recovery of benthic biota to fishing. Mar Ecol Prog Ser 311:1-4

* Kemp WM, Boynton WR, Adolf JE, Boesch DF and others (2005) Eutrophication of Chesapeake Bay: historical trends and ecological interactions. Mar Ecol Prog Ser 303:1-29

Kiørboe T, Møhlenberg F, Hamburger K (1985) Bioenergetics of the planktonic copepod Acartia tonsa: relation between feeding, egg production and respiration, and composition of specific dynamic action. Mar Ecol Prog Ser 26:85-97

Kurihara $\mathrm{H}$ (2008) Effects of $\mathrm{CO}_{2}$-driven ocean acidification on the early developmental stages of invertebrates. Mar Ecol Prog Ser 373:275-284

Lee RF, Hagen W, Kattner G (2006) Lipid storage in marine zooplankton. Mar Ecol Prog Ser 307:273-306

Lester SE, Halpern BS, Grorud-Colvert K, Lubchenco J and others (2009) Biological effects within no-take marine 
reserves: a global synthesis. Mar Ecol Prog Ser 384: 33-46

Mackey MD, Mackey DJ, Higgins HW, Wright SW (1996) CHEMTAX - a program for estimating class abundances from chemical markers: application to HPLC measurements of phytoplankton. Mar Ecol Prog Ser 144:265-283

Michaelidis B, Ouzounis C, Paleras A, Pörtner HO (2005) Effects of long-term moderate hypercapnia on acid-base balance and growth rate in marine mussels Mytilus galloprovincialis. Mar Ecol Prog Ser 293:109-118

Pechenik JA (1999) On the advantages and disadvantages of larval stages in benthic marine invertebrate life cycles. Mar Ecol Prog Ser 177:269-297

Pörtner HO (2008) Ecosystem effects of ocean acidification in times of ocean warming: a physiologist's view. Mar Ecol Prog Ser 373:203-217

Purcell JE, Uye SI, Lo WT (2007) Anthropogenic causes of jellyfish blooms and their direct consequences for humans: a review. Mar Ecol Prog Ser 350:153-174

Ritchie KB (2006) Regulation of microbial populations by coral surface mucus and mucus-associated bacteria. Mar Ecol Prog Ser 322:1-14

Rogers CS (1990) Reponses of coral reefs and reef organisms to sedimentation. Mar Ecol Prog Ser 62:185-202

Rohwer F, Seguritan V, Azam F, Knowlton N (2002) Diversity and distribution of coral-associated bacteria. Mar Ecol Prog Ser 243:1-10

Scharf FS, Juanes F, Roundtree RA (2000) Predator size-prey size relationships of marine fish predators: interspecific variation and effects of ontogeny and body size on trophic-niche breadth. Mar Ecol Prog Ser 208:229-248

* Simon M, Azam F (1989) Protein content and protein synthesis rates of planktonic bacteria. Mar Ecol Prog Ser 51: 201-213

* Verity PG, Smetacek V (1996) Organism life cycles, predation, and the structure of marine pelagic ecosystems. Mar Ecol Prog Ser 130:277-293

WWahl M (1989) Marine epibiosis. I. Fouling and antifouling: some basic aspects. Mar Ecol Prog Ser 58:175-189

* Warwick RM, Clarke RR (1995) New 'biodiversity' measures reveal a decrease in taxonomic distinctness with increasing stress. Mar Ecol Prog Ser 129:301-305

Wright SW, Jeffrey SW, Mantoura RFC, Llewllyn CA, Bjørnland T, Repeta D, Welschmeyer N (1991) Improved HPLC method for the analysis of chlorophylls and carotenoids from marine phytoplankton. Mar Ecol Prog Ser 77:183-196

*apata M, Rodríguez F, Garrido JL (2000) Separation of chlorophylls and carotenoids from marine phytoplankton: a new HPLC method using a reversed phase C8 column and pyridine-containing mobile phases. Mar Ecol Prog Ser 195:29-45 